\title{
EFFECT OF PH AND PHOSPHORUS CONCENTRATION ON POTATO MICROTUBERIZATION
}

\author{
M. M. Khalil \\ Potato and Vegetative Propagated Vegetables Research Department, Horticulture \\ Research Institute, Agricultural Research Center, Giza, Egypt.
}

Received: May 27, 2019

Accepted: Jun. 23, 2019

\begin{abstract}
An in vitro study was conducted to investigate the effect of phosphorus concentration and $\mathrm{pH}$ on microtuberization of two potato varieties. Diamant variety produced higher microtuber number while Spunta gave heavier microtubers. Increasing phosphorus concentration to $2 \mathrm{mM}$ gave the best results of microtuber number and average microtuber weight per jar. Moreover, lowering pH for $24 \mathrm{hr}$. produced higher microtuber number and average microtuber weight per jar. The results demonstrated that increasing phosphorus concentration and $\mathrm{pH}$ temporary lowering could improve microtubers number and weight magnifying the possibility of microtuber utilization in seed potato programs.
\end{abstract}

Key words: Potato, Microtuberization, Phosphorus, pH.

\section{INTRODUCTION}

Potato is the fourth major world food crop produced after maize, wheat and rice (FAO, 2019). In most developing countries the main problem facing the spread of potato cultivation is the lack of high quality seed tubers. The use of tissue culture techniques could improve self-sufficiency of seed potato, reduce number of field generation and reduce disease frequency in the final product. In vitro produced potato tubers (Microtubers) are formed in a wide range of different growing systems with varying environment, media constituents, and storage intervals (Donnelly et al., 2003). Microtubers are used in seed potato program for minituber production (Kawakami et al., 2015). Some studies used microtubers for direct seeding in open field (Pruski et al., 2003; Kawakami, J. and Iwama, K., 2012; Wróbel, 2015). Also, Microtubers are an alternative model for biochemical and physiological studies (Coleman et al., 2001). Furthermore, in vitro microtuberization was used for comparisons between potato genotypes salinity tolerance
(Morpurgo, 1991; Naik and Wildholm, 1993; Zhang and Donnelly, 1997 and Khalil, 2009), heat stress (Gopal and Minoch, 1997) and frost resistance (Martinez et al., 1996).

Phosphorus studies on potato concentrated mainly on yield quantity. Although, some literatures indicated that phosphorus play a role in increasing potato tuber number in open field (Freeman et al. 1998; Jenkins and Ali 2000; Rosen et al. 2014) and in solution cultures (Rolot and Seutin 1999; Rolot et al., 2002). Another factor was manipulated by researcher is the acidity of the nutrient medium; Wan et al. (1994) stated that reducing $\mathrm{pH}$ in solution culture increased potato tuber numbers. Recently Teng et al. (2019) mentioned that acid pretreatment can efficiently promote microtuber formation and growth, which can be used for industrial production of potato seeds. On the other hand, Oraby et al., (2015) indicated that reducing $\mathrm{pH}$ reduced growth and tuber number. The optimum $\mathrm{pH}$ for tuberization need more studies specially in relation to 
phosphorus availability which could take different trend than in soils because of the rapid shift in $\mathrm{pH}$. The current in vitro study investigates the relationship of phosphorus and temporary acidity on two potato varieties microtuber production to be used in pre-basic seed production program.

\section{MATERIALS AND METHODS}

The plant material for the study were plantlets multiplied in vitro on MS media (Murashige and Skoog, 1962) salts and vitamins supplemented with $30 \mathrm{~g} / \mathrm{l}$ sucrose solidified with 7 g/l agar with adjusted $\mathrm{pH}$ to 5.7 prior autoclaving at $1.05 \mathrm{Kg} / \mathrm{cm}^{2}$ and $121^{\circ} \mathrm{C}$ for $20 \mathrm{~min}$. For the study of the effect of experiment treatments stem segments containing three nodes were cultured on microtuberization medium. The microtuberization liquid medium consisted of MS salts and vitamins with $80 \mathrm{~g} / \mathrm{l}$ sucrose. The culture vessels were $400 \mathrm{~g}$ glass jars containing $50 \mathrm{ml}$ liquid medium. Only one gram of Cotton pieces was used as supporting material in each jar. The $\mathrm{pH}$ was adjusted according to the treatments prior autoclaving. Cultures were incubated at $25 \pm 2^{\circ} \mathrm{C}$ in darkness for 60 days. The treatments of the study contained three factors i.e., two varieties, three phosphorus concentrations and three pH levels. The two varieties were Diamant and Spunta, three phosphorus concentrations were the stander concentration recommended in MS medium $1.25 \mathrm{mM}$ as well as $2 \mathrm{mM}$ and 2.5 $\mathrm{mM}$; potassium phosphate was used as the source of phosphorus and the increase in potassium was adjusted by reducing potassium nitrate concentration and the reduction in nitrate was corrected by ammonium nitrate. The $\mathrm{pH}$ levels used in this experiment to study its effect on microtuber formation were: 1) initial culture for 24 hours on pH 3.5 then transferring to fresh medium with $\mathrm{pH}$ 5.7; 2) initial culture for 24 hours on $\mathrm{pH} 4.0$ then transferring to fresh medium $\mathrm{pH} 5.7$ or 3.5) culture on constant pH (5.7). Each treatment was replicated three times each replicate contained five jars with three stem cuttings in each jar. Data of microtuber number per explant, microtuber weight, and weight of the largest microtuber per jar, microtubers weight per jar and microtuberization ratio (percent of the number of tuberized explants divided by the total number of explants) were determined after 60 days. The experiment contained $18(2 \times 3 \times 3)$ treatments laid out in a factorial $(2 \times 3 \times 3)$ in completely randomized design. The experiment was repeated twice its results were analogous hence data presented for the last one. Statistix 10 software was used for data analysis; separation between means was performed by the L.S.D at $5 \%$ level (Snedecor and Cochran, 1980).

\section{RESULTS AND DISCUSSION}

The main effects of the varieties, phosphorus concentrations and $\mathrm{pH}$ levels on microtuber number were illustrated in Fig. (1-a). Diamant cv. produced higher average microtuber number and tuberization ratio than Spunta cv. (Fig. 1-d). Increasing the phosphorus concentration from stander concentration in MS media $(1.25 \mathrm{mM})$ to 2 $\mathrm{mM}$ produced the highest microtuber number (Fig 1-b) followed by $2.5 \mathrm{mM}$, however the stander phosphorus concentration in MS medium produced the lowest average microtuber number and tuberization ratio (Fig. 1-e).

According to $\mathrm{pH}$ effect (Fig. 1-c, f), lowering $\mathrm{pH}$ to 3.5 before transferring to stander $\mathrm{pH}(5.7)$ resulted in the highest average number of microtuber and tuberization ratio followed by initial $\mathrm{pH}$ 4.0 comparing with constant pH 5.5. 


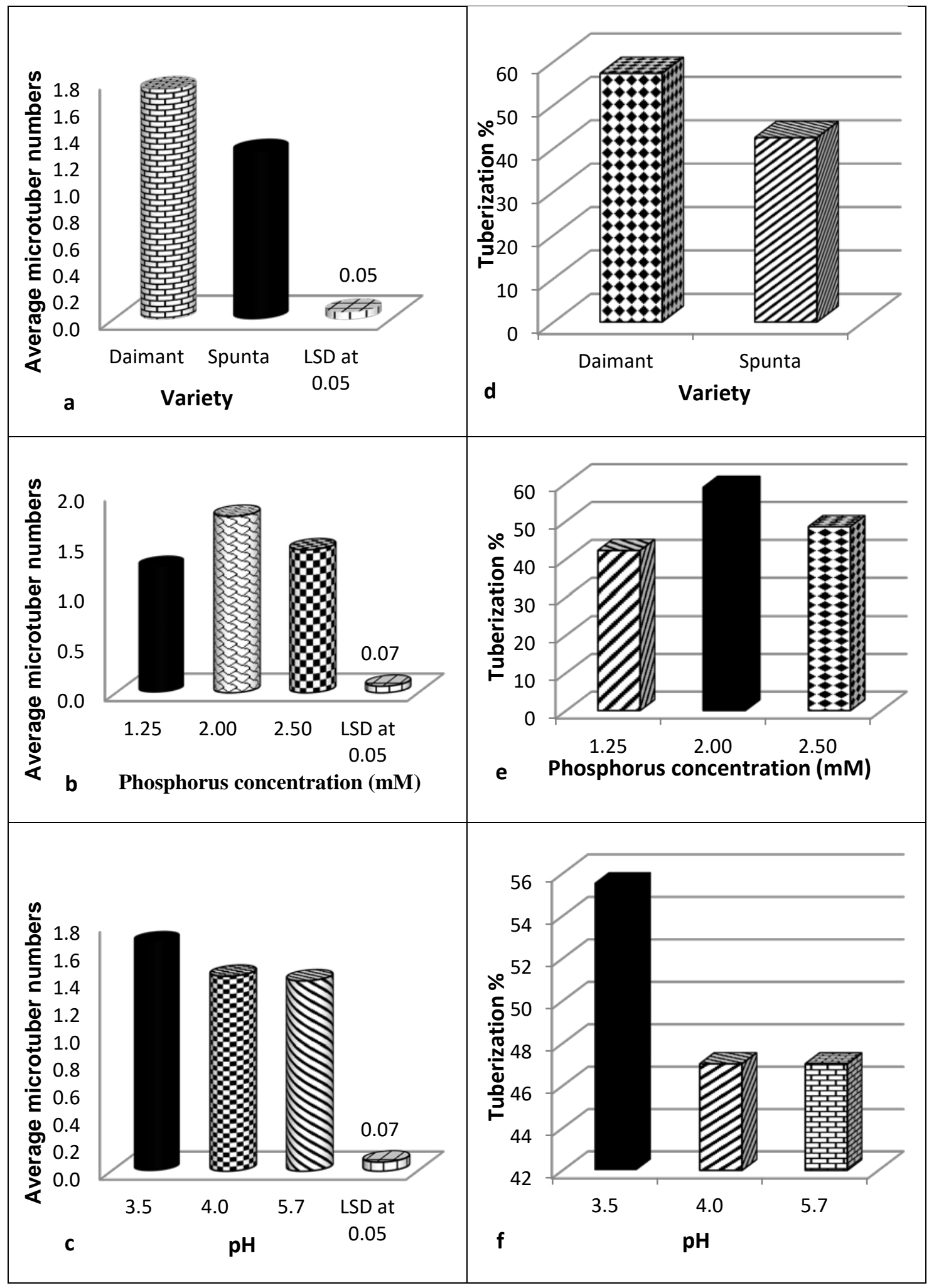

Fig.1: Main effects of varieties, phosphourus concentration and initial pH on microtuber number per explant (a., b. and c. respectively) and on tuberization ratio (d., e. and f. respectively). 
The interaction between varieties and phosphorus concentration showed that the significant highest average of microtuber number produced when Diamant variety combined with $2 \mathrm{mM}$ Phosphorus (Table 1). Also, the interaction between varieties and $\mathrm{pH}$ was significant thus the highest average of microtuber number produced by Diamant cv. on initial pH 3.5. Furthermore, the interaction between phosphorus and $\mathrm{pH}$ was significant with the highest average microtuber number in $2 \mathrm{mM} P$ either with pH 5.7 or initially on pH 3.5 before transferring to $\mathrm{pH}$ 5.7. Data presented in Table 1. show the significant effect of interaction between the three tested factors on average tuber number; as Diamant variety gave the largest average microtubers number when initially cultured on pH 3.5 with $2 \mathrm{mM}$ phosphorus.

Regarding to the average of individual microtuber weight, Spunta cv. formed heavier microtubers than Diamant (Fig. 2a, 3, 4). Furthermore, stander phosphorus concentration 1.25 produced higher average of microtuber weight (Fig. 2-b). Moreover, lowering initial pH to 4 or 3.5 increased the average of microtuber weight than culture on constant pH 5.7 (Fig. 2-c). Concerning the interaction between varieties and phosphorus concentration, Spunta cv. cultured on 1.25 or $2 \mathrm{mM}$ gave the highest average of microtuber weight comparing with other combinations between the two varieties and phosphorus concentrations. Also, Spunta cultured on initial $\mathrm{pH} 3.5$ gave the highest average of microtuber weight in comparison with other combinations between the two varieties and $\mathrm{pH}$ levels. Regarding the interaction between phosphorus and $\mathrm{pH}$ level; the highest microtuber weight was observed when $\mathrm{P}$ concentration at $2 \mathrm{mM}$ combined with $\mathrm{pH}$ 4 and $P$ concentration at $1.25 \mathrm{mM}$ combined with pH 3.5 (238) or 4 (239).
Furthermore, the triple interaction between varieties, phosphorus and $\mathrm{pH}$ was significant producing the highest average microtuber weight by Spunta explants cultured on stander MS phosphorus concentration (1.25mM) with initial $\mathrm{pH} 3.5$ before transfer to $\mathrm{pH} 5.7$ while the lowest one produced in Diamant in $1.25 \mathrm{mM}$ phosphorus with constant pH 5.7 (Table 1).

Regarding the main effect of varieties, phosphorus concentration and $\mathrm{pH}$ treatments on average microtuber weight per jar was illustrated in Fig. 2; Diamant cv. produced higher microtuber weight per container than Spunta cv. This could be attributed to the increase in Diamant microtubers number which compensates the higher Spunta individual microtuber weight. Two $\mathrm{mM}$ phosphorus concentration gave higher average weight per jar. Furthermore, the highest average microtuber weight per container was obtained by initial 3.5 followed by 4 while constant pH 5.7 gave the lowermost values. Concerning, the interactions between varieties and $P$ concentration; Diamant on 2 or $1.25 \mathrm{mM}$ and Spunta on 2 $\mathrm{mM}$ produced were significantly superior to other treatments. Furthermore, the interaction between varieties and $\mathrm{pH}$ was significant leading to the highest microtuber weight per jar for Diamant on pH 3.5 or 4. Regarding the interaction between phosphorus and pH $1.5 \mathrm{mM}$ or 2 $\mathrm{mM}$ phosphorus with $\mathrm{pH} 3.5$ and $2 \mathrm{mM}$ with any $\mathrm{pH}$ treatment surplus other treatments. The interaction between the three tested factors was significant raising the heaviest microtuber weight per container by Diamant when the medium contained $1.25 \mathrm{mM} P$ was cultured on media adjusted to 3.5 initial $\mathrm{pH}$ without significant difference between Diamant on the medium containing $1 \mathrm{mM}$ phosphorus with initial pH 4 (Fig. 3). 
Table 1: Effect of variety, phosphorus and $\mathrm{pH}$ interactions on microtuber average number per explant, average weight and average weight of largest microtuber per jar.

\begin{tabular}{|c|c|c|c|c|c|}
\hline Variety & $\begin{array}{l}\text { Phosphorus } \\
\text { concentration } \\
\text { (mM) }\end{array}$ & $\mathrm{pH}$ & $\begin{array}{l}\text { Average } \\
\text { microtuber } \\
\text { Number }\end{array}$ & $\begin{array}{c}\text { Average } \\
\text { microtuber } \\
\text { weight }(\mathbf{m g})\end{array}$ & $\begin{array}{l}\text { Average largest } \\
\text { microtuber } \\
\text { weight (mg) }\end{array}$ \\
\hline \multirow[t]{9}{*}{ Daimant } & 1.25 & 3.5 & 2.0 & 214 & 399 \\
\hline & 1.25 & 4.0 & 1.5 & 269 & 415 \\
\hline & 1.25 & 5.7 & 1.1 & 108 & 124 \\
\hline & 2.00 & 3.5 & 2.7 & 134 & 198 \\
\hline & 2.00 & 4.0 & 2.0 & 192 & 414 \\
\hline & 2.00 & 5.7 & 1.6 & 152 & 398 \\
\hline & 2.50 & 3.5 & 1.8 & 136 & 436 \\
\hline & 2.50 & 4.0 & 1.4 & 146 & 310 \\
\hline & 2.50 & 5.7 & 1.4 & 192 & 323 \\
\hline \multirow[t]{9}{*}{ Spunta } & 1.25 & 3.5 & 1.0 & 261 & 443 \\
\hline & 1.25 & 4.0 & 1.0 & 208 & 295 \\
\hline & 1.25 & 5.7 & 1.0 & 233 & 319 \\
\hline & 2.00 & 3.5 & 1.1 & 292 & 475 \\
\hline & 2.00 & 4.0 & 1.0 & 266 & 345 \\
\hline & 2.00 & 5.7 & 2.2 & 165 & 348 \\
\hline & 2.50 & 3.5 & 1.4 & 210 & 282 \\
\hline & 2.50 & 4.0 & 1.6 & 186 & 308 \\
\hline & 2.50 & 5.7 & 1.0 & 237 & 419 \\
\hline LSD at 0.05 & & & 0.16 & 17.1 & 123 \\
\hline \multirow[t]{3}{*}{ Daimant } & 1.25 & & 1.5 & 197 & 313 \\
\hline & 2.00 & & 2.1 & 159 & 337 \\
\hline & 2.50 & & 1.5 & 158 & 356 \\
\hline \multirow[t]{3}{*}{ Spunta } & 1.25 & & 1.0 & 234 & 353 \\
\hline & 2.00 & & 1.4 & 241 & 389 \\
\hline & 2.50 & & 1.3 & 211 & 337 \\
\hline LSD at 0.05 & & & 0.09 & 9.9 & ns \\
\hline \multirow[t]{3}{*}{ Daimant } & & 3.5 & 2.2 & 161 & 344 \\
\hline & & 4.0 & 1.6 & 202 & 380 \\
\hline & & 5.7 & 1.4 & 151 & 282 \\
\hline \multirow[t]{3}{*}{ Spunta } & & 3.5 & 1.2 & 254 & 400 \\
\hline & & 4.0 & 1.2 & 220 & 316 \\
\hline & & 5.7 & 1.4 & 212 & 362 \\
\hline \multirow[t]{10}{*}{ LSD at 0.05} & & & 0.09 & 9.9 & 71 \\
\hline & 1.25 & 3.5 & 1.5 & 238 & 421 \\
\hline & 1.25 & 4.0 & 1.3 & 239 & 355 \\
\hline & 1.25 & 5.7 & 1.1 & 171 & 222 \\
\hline & 2.00 & 3.5 & 1.9 & 213 & 336 \\
\hline & 2.00 & 4.0 & 1.5 & 229 & 380 \\
\hline & 2.00 & 5.7 & 1.9 & 159 & 373 \\
\hline & 2.50 & 3.5 & 1.6 & 173 & 359 \\
\hline & 2.50 & 4.0 & 1.5 & 166 & 309 \\
\hline & 2.50 & 5.7 & 1.2 & 215 & 371 \\
\hline LSD at 0.05 & & & 0.11 & 12.1 & 87 \\
\hline
\end{tabular}




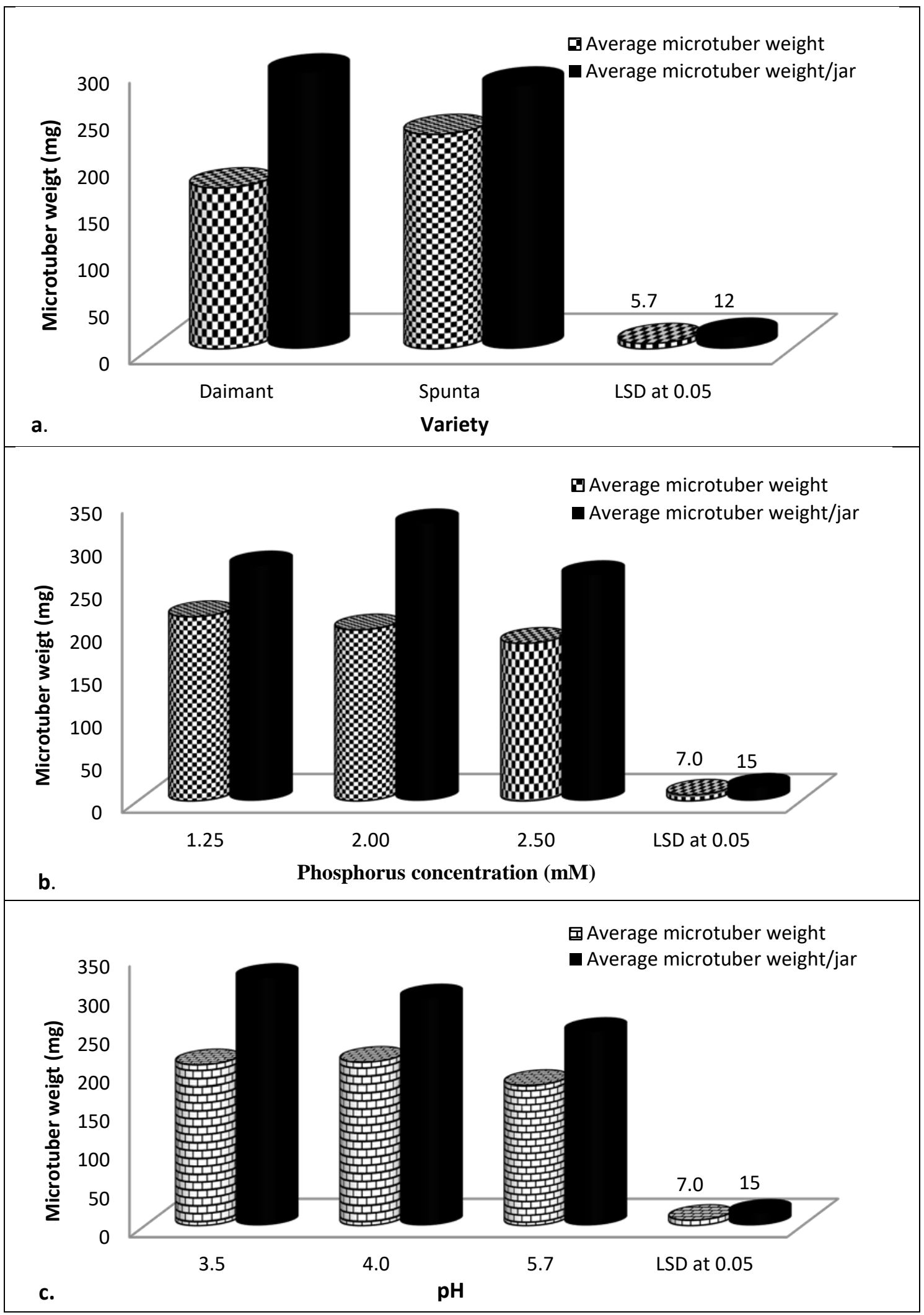

Fig. 2: Main effects of a. varieties, b. phosphorus concentration and c. initial pH on microtuber weight. 


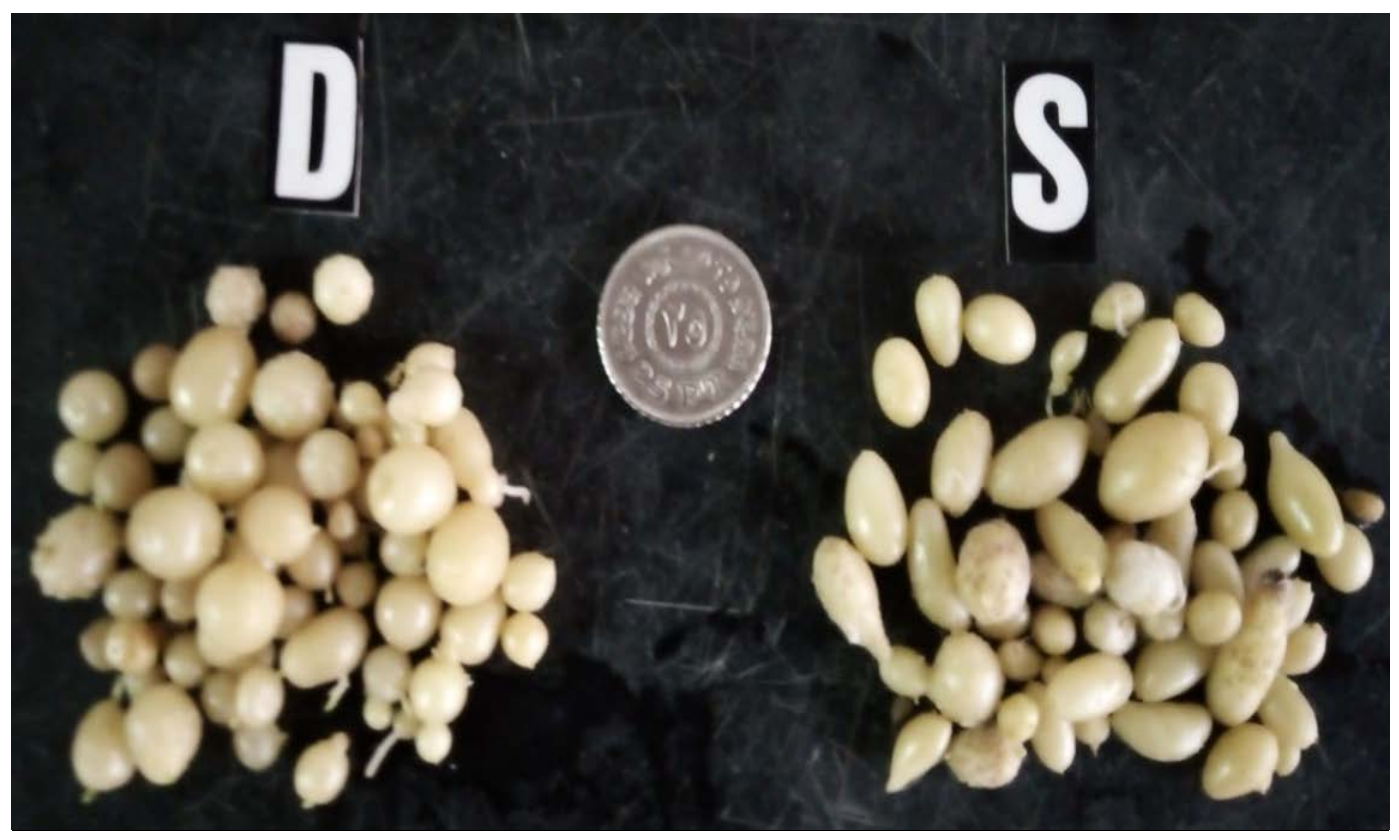

Fig. 3: Diamant (D) and Spunta (S) microtubers.

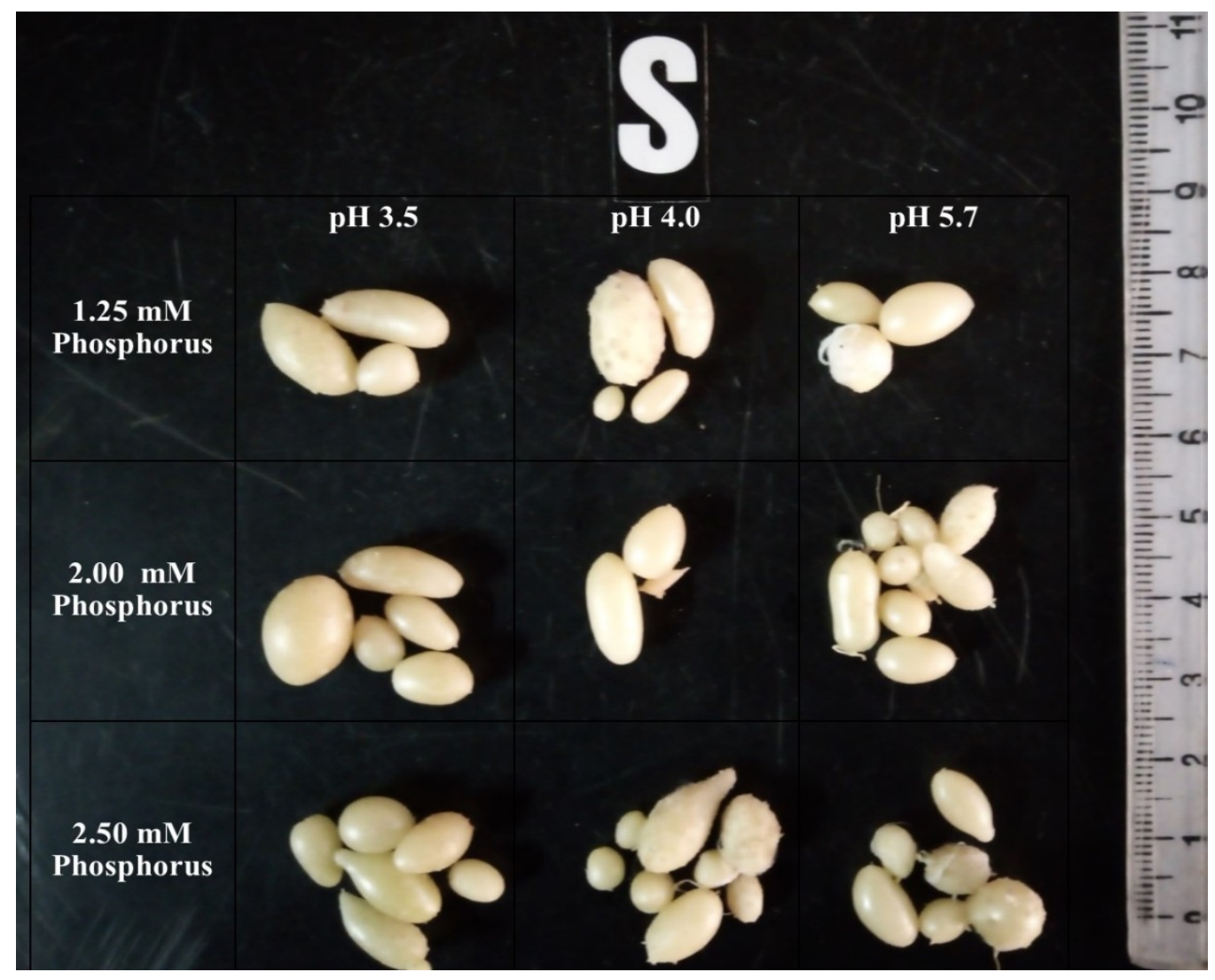

Fig. 4: Spunta microtuber yield on different combinations of phosphorus concentration and initial pH (per one jar). 
The main effects of the three tested factors didn't significantly affect the weight of the largest microtuber per treatment. However, the interaction between the three tested factors effect on the largest microtuber weight was significant (Table 1). In this respect, 7 treatment combinations produced the highest average weight for the largest microtuber i.e., for Spunta 1.25_or $2 \mathrm{mM}$ phosphorus with initial pH 3.5 or $2.5 \mathrm{mM}$

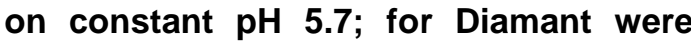
1.25_mM phosphorus with pH 3.5 or 4,2 $\mathrm{mM}$ phosphorus with $\mathrm{pH} 4$ or 5.7 and 2.5 $\mathrm{mM}$ phosphorus with pH 5.7.

The obtained results could be discussed as potato tuberization is a distinctive developmental process controlled by many factors and influenced by the physiological status as a result for that stress could play a major role in driving the plants to tuberization in spite of shoot and root growth. The difference between the two varieties in microtubers number and weight can be related to its genotypic differences (Gopal and Minocha, 1997; Khalil et al., 2017). Regarding the beneficial effects of raising phosphorus concentration to 2 $\mathrm{mM}$, it could be attributed to increasing tuber number of small tubers versus reduced number of large tubers in open field experiments (Benepal, 1967; Sharma and Arora, 1987; Freeman et al., 1998; Jenkins and Ali, 2000; Allison et al. 2001; Kumar et al. 2007; Rosen et al. 2014; Rosen and Bierman, 2008. Although, some reports claimed that $P$ did not affect the total tuber number (Sharma and Arora, 1987; Allison et al., 2001; Mohr and Tomasiewicz, 2011). However, phosphorus is a major player in synthesis and composition of starch (Nielsen et al., 1994; Houghland, 1960). Furthermore, Addition of $P$ had a positive effect in controlling the severity and progression of Mn toxicity symptoms; this effect was pH-dependent and genotype-specific with its effect more prominent at pH 4.0 than 5.8 (Sarkar et al., 2004). Concerning the obtained results of lowering $\mathrm{pH}$ to 3.5 before transferring to stander $\mathrm{pH}(5.7)$ in the same line Teng et al. (2019) mentioned that acid pretreatment resulted in earlier microtuberization, maximum microtuber number per plantlet, fresh and dry weight. Also, Wan et al. (1994) reported that reducing $\mathrm{pH}$ to 3.5 in solution culture resulted in formation of more tubers per plant. Also, Cao and Tibbitts (1994) reported higher plant dry weight obtained in solution culture containing nitrate with pH 5. This effect could be attributed to the inhibition of assimilate partitioning to shoots and roots by lower $\mathrm{pH}$ in favor of tuber initiation However, Oraby et al., (2015) reported that reducing $\mathrm{pH}$ reduced growth and tuber number. The effects of phosphorus concentration and $\mathrm{pH}$ could be related either to availability of nutrients or stress effects favoring tuberization.

From the present study it could be concluded that microtubers number and weight can be improved by manipulation of nutrient media phosphorus concentration and temporary acidity treatment which can lower the cost and enhance the use of microtubers in seed potato programs.

\section{REFERENCES}

Allison, M.F., J.H. Fowler and E.J. Allen (2001). Effects of soil- and foliarapplied phosphorus fertilizers on the potato (Solanum tuberosum) crop. J. Agric. Sci., 137, 379-395.

Benepal, P.S. (1967). Correlations among applied nitrogen, phosphorus and potassium and responses of the 
potato plant. Amer. Potato J., 44: 7586.

Cao, W. and T. W. Tibbitts (1994). Responses of potatoes to solution $\mathrm{pH}$ levels with different forms of nitrogen. J. Plant Nut., 17: 109-126.

Coleman, W.K., D.J. Donnelly and S.E. Coleman (2001). Potato microtubers as research tools: A review. Amer. J. Potato Res., 78:47-55.

Donnelly, D.J., S.E. Coleman and W.K. Coleman (2003). Potato microtuber production and performance: A review. Amer. J. Potato Re., 80: 103115.

FAO (2019). Food and Agriculture Organization Database. Retrieved from www.fao.org/faostat.

Freeman, K.L., P.R. Franz and R.W. de Jong (1998). Effect of phosphorus on the yield, quality and petiolar phosphorus concentrations of potatoes (cv. Russet Burbank and Kennebec) grown in the krasnozem and duplex soils of Victoria. Aust. $J$. Exp. Agric., 38: 83-93.

Gopal, J. and J.L. Minocha (1997). Effectiveness of selection at microtuber crop level in potato. Plant Breeding, 116: 293-295

Houghland, G.V.C. (1960). The influence of phosphorus on the growth and physiology of the potato plant. Amer. J. Potato Res., 37: 127-138.

Jenkins, P.D. and H. Ali (2000). Phosphate supply and progeny tuber numbers in potato crops. Ann. Appl. Biol., 136, 41-46.

Kawakami, J. and K. Iwama (2012) Effect of potato microtubers size on the growth and field performance of field grown plants. Plant Prod. Sci. 15, 144148.

Kawakami, T., H. Oohori and K. Tajima (2015). Seed potato production system in Japan, starting from foundation seed of potato. Breeding Sci. 65 (1): 17-25

Khalil, M. M. (2009). Comparative studies on in vitro and in vivo salt tolerance of potato plants. PhD. Thesis Ain Shams Univ. 165 pp.

Khalil, M.M., A.M.H. Abd El Aal and M.M. Samy (2017). Studies on microtuberization of five potato genotypes. Egypt. J. Hort., 44 (1): 9197.

Kumar, P., S.K. Pandey, B.P. Singh, S.V. Singh and D. Kumar (2007). Optimizing phosphorus requirement of chipsona varieties for west-central plains of india. Potato J., 34: 199-202.

Martinez, C.A., M. Maestri and E.G. Lani (1996). In vitro salt tolerance and proline accumulation in Andean potato (Solanum spp.) differing in frost resistance. Plant Sci., 116: 177184.

Mohr, R.M. and D.J. Tomasiewicz (2011). effect of phosphorus fertilizer rate on irrigated Russet Burbank potato. Commun. Soil Sci. Plant Anal., 42, 2284-2298.

Morpurgo, R. (1991). correlation between potato clones grown in vivo and in vitro under sodium chloride stress conditions. Plant Breeding, 107: 8082.

Murashige, T. and F. Skoog (1962). A revised medium for rapid growth and bio assays with tobacco tissue cultures. Physiol. Plant., 15: 473-479.

Naik, P.S. and J.M. Widholm (1993). Comparison of tissue culture and whole plant responses to salinity in potato. Plant Cell Tiss. Organ Cult., 33, 273-280.

Nielsen, T.H., B. Wischmann, K. Enevoldsen and B.L. Moller (1994). Starch phosphorylation in potato tubers proceeds concurrently with de novo biosynthesis of starch. Plant Physiol., 1: 111-117. 
Oraby, H., A. Lachance and Y. Desjardins (2015). A low nutrient solution temperature and the application of stress treatments increase potato mini-tubers production in an aeroponic system. Amer. J. Potato Res., 92, 387-97.

Pruski, K., T. Astatkie, P. Duplessis, L. Stewart, J. Nowak and P.C. Struik (2003). Manipulation of microtubers for direct field utilization in seed production. Amer. J. Potato Res. 80, 173-181.

Rolot, J., H. Seutin and D. Michelante (2002). Production de minitubercules de pomme de terre par hydroponie: évaluation d'un système combinant les techniques "NFT" et "Gravel Culture" pour deux types de solutions nutritives. Biotechnol. Agron. Soc. Environ., 6: 155-161.

Rolot, J.L. and H. Seutin (1999). Soilless production of potato minitubers using a hydroponic technique. Potato Res., 42: 457-469.

Rosen, C.J. and P.M. Bierman (2008). Potato yield and tuber set as affected by phosphorus fertilization. Amer. J. Potato Res., 85: 110-120.

Rosen, C.J., K.A. Kelling, J.C. Stark and G.A. Porter (2014). optimizing phosphorus fertilizer management in potato production. Amer. J. Potato Res., 91, 145-160.

Sarkar, D., S.K. Pandey, K.C. Sud and A. Chanemougasoundharam (2004). In vitro characterization of manganese toxicity in relation to phosphorus nutrition in potato (Solanum tuberosum L.). Plant Sci., 167, 977986.

Sharma, U.C. and B.R. Arora (1987). Effect of nitrogen, phosphorus and potassium application on yield of potato tubers (Solanum tuberosum L.). J. Agric. Sci., 108: 321-329.

Snedecor, G.W. and W.G. Cochran (1980). "Statistical Methods", $7^{\text {th }}$ ed., lowa state Univ., Press, lowa, U. S. A.

Teng, Y., Y. Zhang, J.T. Guo, Y.L. Gao and K.H. Li (2019). Acid pretreatment improves microtuberization of potato plantlets. In Vitro Cell. Dev. Biol. Plant, 55:36-43.

Wan, W.Y., W. Cao and T.W. Tibbitts (1994). Tuber initiation in hydroponically grown potatoes by alteration of solution pH. HortSci., 29: 621-623.

Zhang, Y. and D.J. Donnelly (1997). In vitro ranking for salinity tolerance of potato cultivars. Potato Res., 40:285295. 
تأثير درجة الحموضة وتركيز الفوسفور على تكوين درينات البطاطس

\author{
محمد مصطفى على خليل
}

قسم بحوث البطاطس والخضر خضرية التكاثر، معهد بحوث البساتين، مركز البحوث الزراعية، الجيزة، مصر.

الملخص العربى

أجريت دراسة معملية لبحث تأثير تركيز الفوسفور ودرجة الحموضة على تكوين الدرينات لصنفي بطاطس. أنتج

الصنف دايامونت عدد أكبر من الدرينات بينما أعطى الصنف سبونتا درينات أكبر وزنا. أدى رفع تركيز الفوسفور ل r

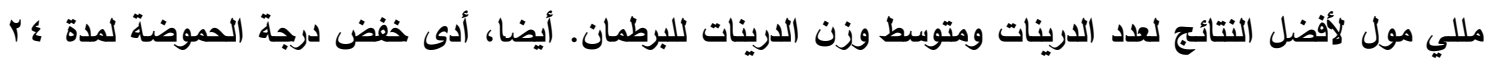
ساعة لإنتاج أعلى عدد من الدرينات ومتوسط وزن الدرينة للبرطمان. تبين النتائج إمكانية تحسين أعداد وأوزان الدرينات بزيادة تركيز الفوسفور والخفض المؤقت لارجة الحموضة مما يعظم من إمكانية استخدامها في برامج انتاج تقاوي البطاطس. كلمات مفتاحية: بطاطس، تكوين الارينات، فوسفور، درجة الحموضة.

أسماء السادة المحكمين

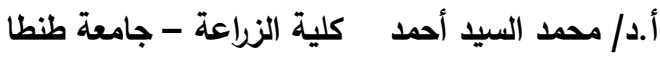

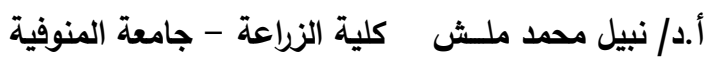

